\title{
Implementasi Manajemen Syariah Pegadaian Dalam Gadai Emas
}

\author{
Mela Tiyas Wijayanti \\ PT. Pegadaian (Persero) \\ mickeynice83@yahoo.com
}

\begin{abstract}
This study aims to examine the management of Sharia Pegadaian in building consumer trust in gold pawning. This study used qualitative research methods. The data collection technique used are interview documentation studies. Data analysis uses reduction techniques, data presentation and conclusion drawing. The results of the study indicate that Sharia management at Pegadaian has been running in increasing consumer confidence in gold pawning. The evidence comes from the increasing number of consumers for gold pawning every month at the Kartini Sharia Pawnshop. Motivation and support of the Kartini Sharia Pawnshop Branch Leader makes employees feel happy and comfortable so that employee performance can be maintained to the maximum. This consumer trust can be seen from the attitudes and interests of consumers who transact at Kartini Sharia Pawnshop. In addition to gold pawning, consumers can also invest in gold, purchase motorized vehicles, pilgrimage, and pay for electricity, telephone, water and insurance at Pegadaian. Like the motto of Pegadaian overcoming problems without problems. This research is useful in providing input to maintain consumer trust in the withdrawal of consumer savings for the nearest area, especially Denpasar, especially for institutions, traders and micro and medium business owners. Therefore, it is expected that further researchers will discuss more about ways to increase consumers for gold pawns and other products in a more modern way along with the era that continues to advance.
\end{abstract}

Keywords: sharia management; consumer trust; gold 
Penelitian ini bertujuan untuk meneliti manajemen Syariah Pegadaian dalam membangun kepercayaan konsumen untuk gadai emas. Penelitian ini menggunakan metode penelitian kualitatif. Teknik pengumpulan data yang digunakan adalah dengan menggunakan metode wawancara dan studi dokumentasi. Analisis data menggunakan teknik redusi, penyajian data dan penarikan kesimpulan. Hasil penelitian menunjukkan bahwa manajemen Syariah di Pegadaian sudah berjalan dalam meningkatkan kepercayaan konsumen untuk gadai emas. Hal ini terbukti dengan meningkatnya konsumen untuk gadai emas setiap bulannya di Pegadaian Syariah Kartini. Motivasi dan dukungan Pimpinan Cabang Pegadaian Syariah Kartini membuat karyawan merasa senang dan nyaman sehingga kinerja Pegawai dapat dipertahankan dengan maksimal. Kepercayaan konsumen ini dapat dilihat dari sikap dan minat konsumen yang bertransaksi di Pegadaian Syariah Kartini. Selain gadai emas, konsumen juga dapat berinvestasi emas, pembelian kendaraan bermotor, ibadah haji, hingga pembayaran listrik, telepon, air, maupun asuransi di Pegadaian. Seperti semboyan Pegadaian mengatasi masalah tanpa masalah. Penelitian ini bermanfaat memberikan masukan untuk mempertahankan kepercayaan konsumen, dapat dilakukan penarikan tabungan konsumen untuk wilayah terdekat terutama Denpasar khususnya untuk instansi, pedagang dan pemilik usaha mikro serta menengah. Oleh karena itu diharapkan peneliti selanjutnya lebih banyak membahas cara peningkatan konsumen untuk gadai emas maupun produk lainnya dengan cara yang lebih modern seiring dengan jaman yang terus maju.

\section{Kata kunci : manajemen Syariah; kepercayaan konsumen; emas}




\section{PENDAHULUAN}

Dewasa ini perkembangan ekonomi dan bisnis yang berbasis Syariah semakin marak, seperti Pegadaian Syariah, Bank Syariah, KPR Syariah, Asuransi Syariah dan lain - lain. Ketidakberdayaan sistem ekonomi kapitalis, sosialis, dan berbagai system lainnya untuk memberikan jawaban terhadap permasalahan bangsa, baik itu kemiskinan, pengangguran, ketertinggalan, kriminalitas, dan lain sebagainya, bukti kuat bahwa ekonomi Syariah adalah solusi di tengah - tengah kegalauan masyarakat Indonesia selama ini. Sistem ekonomi Syariah adalah alternatif yang pas dalam mencari jalan keluar dari kemelut ekonomi sekarang ini.

Dalam Adil, 2017 Syariah Islam memiliki keunikan tersendiri, bukan saja menyeluruh atau komprehensif tetapi juga universal. Komprehensif berarti Syariah Islam merangkum seluruh aspek kehidupan, baik ritual (ibadah) maupun sosial (muamalah). Ibadah diperlukan untuk menjaga ketaatan dan keharmonisan hubungan manusia dengan robb - Nya. Universal memiliki arti Syariah Islam dapat diimplementasikan dalam setiap waktu dan tempat sampai hari akhir nanti. Universalitas ini tampak dalam bidang muamalah (social). Selain mempunyai cakupan luas dan fleksibel, muamalah tidak membeda - bedakan antara muslim dan non - muslim.

Saat ini perkembangan produk - produk berbasis Syariah kian marak di Indonesia, tidak terkecuali PT pegadaian (persero). Dalam realita kehidupan sosial masyarakat sering ditemukan masyarakat yang memiliki harta selain uang tunai dan disaat bersamaan yang bersangkutan memiliki kesulitan dan membutuhkan biaya dalam bentuk tunai, dan pilihan masyarakat yang sering dilakukan adalah menggadaikan harta yang mereka miliki. Pegadaian memiliki motto "mengatasi masalah tanpa masalah". Dengan motto itu diharapkan masyarakat tidak lagi malu atau ragu untuk datang ke Pegadaian (Nasution, 2016).

Pegadaian Syariah atau dikenal dengan istilah rahn, dalam pengoperasiannya menggunakan dua akad yaitu akad gadai dan akad mu'nah. Karena nasabah dalam mempergunakan marhunbih (UP) mempunyai tujuan yang berlainan misalnya untuk konsumsi, membayar biaya sekolah, investasi maupun tambahan modal kerja. Jasa titip dikenakan persepuluh hari dan tempo yang diberikan dalam akad gadai adalah empat bulan.

Pegadaian Syariah adalah Pegadaian yang menjalankan operasionalnya berpegang kepada prinsip Syariah. Pelindung gadai Syariah dalam pemenuhan prinsip - prinsip Syariah berpegang Fatwa DSN - MUI Nomor 25/DSN/MUI/III/2002 tentang rahn, Fatwa DSN - MUI Nomor 26/DSN-MUI/III/2002 tentang rahn emas, Fatwa DSN - MUI Nomor 68/DSNMUI/III/2002 tentang rahn tasjily, Fatwa DSN - MUI 92/DSN - MUI/III/2002 tentang 
pembiayaan yang disertai dengan rahn (At Tamwil Al Mautsuq bi al Rahn) Amanah, Arrum, Rahn Tasjily tanah. Pegadaian Syariah tidak mengenal system bunga, karena keberadaan gadai Syariah dimaksudkan untuk memenuhi kebutuhan masyarakat dengan menggunakan prinsip Syariah yakni muamalah dan transaksi tanpa riba, karena riba dianggap tidak sesuai dengan hukum Islam, dalam gadai Syariah dikenal dengan istilah mu'nah atau jasa titip.

Landasan hukum dalam pembentukan Pegadaian Syariah ini adalah Alquran dan Hadits. Dasar hukum praktek gadai secara normatif dapat digali dalam surat Al Baqarah ayat : 282 dan ayat : 283 yang mengajarkan perjanjian hutang piutang yang perlu diperkuat dengan catatan dan melibatkan saksi-saksi. Landasan gadai (Rahn), sebagaimana halnya dengan jual - beli, gadai diperbolehkan, karena segala sesuatu yang boleh dijual boleh digadaikan.

Saat ini di Provinsi Bali, telah ada 19 kantor Cabang Pegadaian (CP) dan 109 Unit Pelayanan Cabang (UPC) sementara untuk Pegadaian Syariah terdapat 2 Cabang Pegadaian Syariah dan 6 Unit Pelayanan Syariah (UPS). Hal ini menunjukkan bahwa Pegadaian telah menjadi salah satu alternatif pembiayaan bagi masyarakat di Propinsi Bali. Salah satu program pembiayaan yang ditawarkan Pegadaian Syariah adalah gadai emas. Menyimpan emas, baik emas dalam bentuk perhiasan maupun logam mulia sebagai sarana investasi telah menjadi budaya pada masyarakat kita.

Kepercayaan konsumen adalah semua pengetahuan yang dimiliki oleh konsumen, dan semua kesimpulan yang dibuat oleh konsumen tentang objek, atribut, dan manfaatnya. Kepercayaan konsumen terhadap suatu produk, atribut, dan manfaat produk menggambarkan persepsi konsumen. Oleh sebab itu, kepercayaan akan berbeda diantara konsumen.

Abu bakar dan Astuti 2012, mengatakan praktik pegadaian khususnya gadai emas Syariah yang semula berfungsi sebagai alternatif pembiayaan yang cepat dan murah berbasis kekuatan sendiri namun saat ini bergeser menjadi salah satu sarana investasi yang spekulatif.

Sampai saat ini emas masih dianggap sebagai sarana investasi yang paling menguntungkan, emas juga sebagai pelindung asset bagi mereka yang memilih risiko investasi yang ringan. Emas juga memiliki nilai jual yang tinggi dibandingkan dengan komoditi investasi lainnya. Berdasarkan hal diatas maka peneliti memiliki motivasi untuk melakukan penelitian di Pegadaian Syariah Kartini karena pembiayaan yang paling banyak diminati masyarakat adalah gadai emas, selain itu nasabah kebanyakan berasal dari orang orang sekitar Cabang Kartini karena dekat dengan pasar dan Rumah Sakit Umum Wangaya, dimana Pegadaian Syariah Cabang Kartini merupakan alternatif tempat terdekat dan tercepat memperoleh dana. 


\section{Manajemen Syariah Pegadaian}

Griffin, 2013 mengemukakan definisi manajemen sebagai serangkaian kegiatan termasuk perencanaan dan pembuatan keputusan, pengorganisasian, pimpinan dan pengendalian yang diarahkan pada sumberdaya organisasi meliputi tenaga kerja, keuangan, fisik, dan informasi yang bertujuan untuk mencapai sasaran organisasi dengan cara yang efisien dan efektif. Ekonomi Islam identik dengan prinsip Syariah, dikatakan oleh Syafuri, 2014. Salah satu jasa keuangan dengan prinsip - prinsip ekonomi Islam adalah gadai Syariah. Syariah merupakan ajaran Islam tentang hukum Islam atau peraturan yang harus dilaksanakan atau ditinggalkan oleh manusia.

Menurut Hamali, 2016 manajemen berasal dari kata kerja bahasa Inggris to manage, yang artinya mengurus, mengatur, melaksanakan, dan mengelola sedangkan definisi manajemen menurut Sudaryono, 2017 mengalami perkembangan arti manajemen adalah ilmu dan seni yang terdiri atas perencanaan, pengorganisasian, pengarahan, dan pengawasan terhadap kinerja organisasi dengan menggunakan sumber daya yang dimiliki untuk mencapai tujuan dan sasaran organisasi.

Dikatakan oleh Adil, 2017 Syariah adalah hukum - hukum yang mengatur hubungan manusia dengan Khaliq maupun dengan makhluk. Syariah Islam memiliki keunikan tersendiri bukan saja menyeluruh atau komprehensif tetapi juga universal. Komprehensif berarti Syariah Islam merangkum seluruh aspek kehidupan baik ritual (ibadah) maupun social (muamalah). Muamalah diturunkan menjadi aturan main manusia dalam kehidupan social. Universal memiliki arti Syariah Islam dapat diimplementasikan dalam setiap waktu dan tempat sampai hari akhir nanti. selain mempunyai cakupan luas dan fleksibel, muamalah tidak membeda - bedakan antara muslim dan non muslim.

\section{Manajemen Syariah}

Islam tidak menentang prinsip konvensional, bahkan mendorong prinsip tersebut. Manajemen Syariah sebagai alternatif pilihan untuk menunjang perbaikan ekonomi di Indonesia. Manajemen Syariah adalah suatu pengelolaan untuk memperoleh hasil optimal yang bemuara pada pencarian keridhaan Allah. Oleh sebab itu maka segala sesuatu langkah yang diambil dalam menjalankan manajemen tersebut harus berdasarkan aturan - aturan Allah. Aturan-aturan itu tertuang dalam Alquran, hadist dan beberapa contoh yang dilakukan oleh para sahabat Nabi Muhammad SAW. Sehubungan dengan itu maka isi dari manajemen Syariah adalah segala sesuatu yang berhubungan dengan ilmu manajemen 
konvensional yang diwarnai dengan aturan Alquran, hadist dan beberapa contoh yang dilakukan oleh para sahabat. (Nurul S, 2019).

\section{Pegadaian Syariah}

Pegadaian Syariah sebagai salah satu unit bisnis Pegadaian. PT Pegadaian (persero) merupakan Badan Usaha Milik Pemerintah (BUMN) di bawah Departemen keuangan (Kementerian Keuangan). Pegadaian masih menggunakan dua institusi regulator yaitu pertama, dasar hukum menggunakan regulasi UU No.10 Tahun 1998 tentang perbankan 71 yang dikeluarkan oleh Bank Indonesia dengan mengikuti regulasi skim Syariah. Kedua, secara operasional mengacu pada standar Pegadaian sebagai induknya yang dikeluarkan oleh Departemen Keuangan berdasarkan Peraturan Pemerintah (PP) No.10 Tahun 1990, tanggal 10 April 1990 (Rodoni, 2015).

Pegadaian Syariah merupakan salah satu bisnis syariah yang lagi moncer di Indonesia. Berkembangnya Pegadaian Syariah sudah semakin pesat, ditandai dengan munculnya produk - produk yang berbasis Syariah. Gadai menjadi solusi masyarakat dalam memenuhi kebutuhan. Perbankan Syariah pun mulai tertarik untuk menerima gadai emas sebagai salah satu produk yang dapat diandalkan. Dengan adanya berbagai lembaga keuangan yang menerima gadai emas, membuat masyarakat mempunyai banyak pilihan untuk gadai emas (Auliyah, 2016). Teknik transaksi Pegadaian Syariah diantaranya :

\section{Akad Rahn}

Dalam hal ini akad rahn menjadi awal berlakunya proses penahanan barang milik peminjam sebagai jaminan dari uang yang diterima. Dengan akad ini pihak Pegadaian memiliki hak menahan barang jaminan untuk uang konsumen. Orang yang menggadaikan disebut rahin, sedangkan orang yang menerima gadai disebut murtahin. Barang yang digadaikan disebut marhun dan pinjaman yang diberikan disebut marhun bih. Untuk gadai ada persyaratan yang harus dipenuhi. Calon konsumen harus memiliki KTP/SIM/Paspor. Barang yang digadai harus memiliki nilai berupa emas, sertifikat tanah, barang elektonik, kendaraan bermotor, dan BPKB. Barang jaminan yang dijaminkan harus memiliki nilai ekonomis, bisa dimanfaatkan, jelas, dapat ditentukan secara spesifik, dan tidak terkait dengan hak kepemilikan orang lain. Demikian pula dengan marhun bih yang diberikan harus jelas. 


\section{Akad Mu'nah}

Akad Mu'nah merupakan akad untuk barang yang digadaikan melalui jasa titip yang dikenakan, namun tidak disertai dengan pemindahan kepemilikan barang. Dalam akad gadai Syariah ini terdapat beberapa rukun seperti orang yang berakad yaitu rahin dan murtahin, ada akad rahn dan akad mu'nah, marhun, dan marhun bih. Tata cara system Pegadaian Syariah (Rahn) cukup mudah dipahami. Melalui akad rahn nasabah memberikan barang jaminan dan selanjutnya pihak Pegadaian Syariah akan menyimpan barang jaminan di tempat yang sudah disediakan. Dalam hal ini, pihak Pegadaian dibenarkan untuk mengenakan jasa titip kepada konsumen (rahin) dengan jumlah sesuai kesepakatan bersama sehingga pihak Pegadaian mendapatkan keuntungan dari bea jasa titip dan bukan bunga dari besar uang yang dipinjamkan.

Mekanisme Pegadaian Syariah ini dirasa memberi banyak manfaat dan keuntungan. Salah satunya, bagi masyarakat yang tengah membutuhkan dana mendesak sekiranya bisa mendapat kemudahan dan keamanan dengan mekanisme Pegadaian Syariah (Suhariyanto, 2015). Kelebihan Pegadaian Syariah antara lain :

1. Halal

Lembaga keuangan Syariah menganut prinsip - prinsip yang berlandaskan nilai - nilai Islam sehingga pengelolaannya terlepas dari riba.

2. Sebagai media beramal

Lembaga keuangan Syariah menyisihkan 2,5\% dari keuntungannya untuk zakat.

3. Tahan terhadap krisis ekonomi

Industri keuangan Syariah mampu melewati masa krisis ekonomi global yaitu tahun 2008 - 2011. Ketika itu pertumbuhan asset tetap mencapai $17,1 \%$, dimana ketika itu banyak industry yang mengalami resesi.

4. Menggunakan sistem gadai Syariah yang adil dan menentramkan. Lembaga Keuangan Syariah menerapkan system pembagian laba dan rugi secara adil. Resiko ditanggung bersama dan proporsional antara pihak yang meminjamkan dan yang menerima pinjaman.

5. Menguatkan Perekonomian Bangsa

Lembaga keuangan Syariah melarang segala aktivitas yang merugikan nasabah dan masyarakat secara umum. Aktivitas itu meliputi riba, spekulasi, dan perjudian. Keberadaan lembaga - lembaga keuangan Syariah sangat potensial dalam menguatkan perekonomian bangsa, dimana hal ini terlihat daya tahannya menghadapi krisis ekonomi. 


\section{Sejarah dan Perkembangan Manajemen Syariah Pegadaian}

Dikatakan oleh Adil 2017, tonggak awal kebangkitan Pegadaian dalam sejarah dikatakan dengan terbitnya PP/10 tanggal 1 April 1990. Perlu dicermati PP/10 menegaskan misi yang harus diemban Pegadaian untuk mencegah praktik riba, dimana misi ini tidak berubah hingga terbit PP103/2000 yang dijadikan landasan kegiatan usaha Pegadaian sampai sekarang. Berkat Rahmat Allah SWT dan melalui kajian panjang, disusunlah konsep pendirian Unit Layanan Gadai Syariah sebagai langkah awal pembentukan divisi khusus yang menangani kegiatan usaha Syariah. Konsep operasi Pegadaian Syariah mengacu pada system administrasi modern yaitu asas rasional, efesiensi dan efektivitas yang diselaraskan dengan nilai Islam. Unit Layanan Gadai Syariah ini merupakan salah satu unit bisnis struktural terpisah pengelolaannya dari usaha gadai konvensional.

Pada tahun 2002 mulai diterapkan system Pegadaian Syariah, kemudian tahun 2003 Pegadaian Syariah resmi beroperasi dan Pegadaian Cabang Dewi Sartika menjadi Kantor Cabang Pegadaian pertama yang menerapkan system Pegadaian Syariah. Pegadaian Syariah pertama berdiri di Jakarta dengan nama Unit Layanan Gadai Syariah (ULGS) Cabang Dewi Sartika pada bulan Januari 2003. Kemudian disusul dengan pendirian ULGS Surabaya, Makasar, Semarang, Surakarta, dan Yogyakarta di tahun yang sama sampai September 2003. Masih dengan tahun yang sama di Aceh 4 kantor cabang dikonversi menjadi Pegadaian Syariah (Rodoni, 2015).

\section{Produk - produk Pegadaian Syariah}

Saat ini lembaga keuangan Syariah di Indonesia semakin menjamur. Hampir setiap lembaga perbankan dan non perbankan mempunyai unit usaha yang menerapkan sistem Syariah, termasuk Pegadaian Syariah. Pegadaian Syariah merupakan unit usaha dari PT Pegadaian, salah satu lembaga keuangan milik pemerintah. Unit bisnis ini tidak hanya menyediakan produk berbasis gadai, melainkan memberikan layanan pembiayaan lain dengan prinsip Syariah. Dalam artikel duitpintar, 2018 disebutkan delapan jenis produk Pegadaian Syariah antara lain: Produk Pegadaian Syariah, dari pinjaman hingga investasi emas yaitu:

\section{Rahn (Gadai Syariah)}

Untuk gadai Syariah tempo yang diberikan adalah 4 bulan. Perhitungan sewa modal yang diberikan adalah persepuluh hari. Layanan ini bisa dilakukan di seluruh outlet Pegadaian Syariah. 


\section{Arrum Haji}

Pegadaian Syariah memiliki produk untuk orang - orang yang ingin menunaikan ibadah Haji. Produk ini disebut Arrum Haji. Produk Arrum Haji memberikan kemudahan kepada konsumen yang berencana pergi Haji ke tanah suci tetapi dana yang dimiliki belum cukup. Pegadaian Syariah memberi dana talangan kepada konsumen agar dana tersebut dapat diangsur sesuai kemampuan konsumen. Dengan mendaftar Arrum Haji konsumen sudah memiliki porsi Haji.

\section{Arrum}

Pegadaian Syariah memiliki produk bagi orang - orang yang ingin memperoleh modal untuk pengembangan usaha. Produk Arrum BPKB dan Arrum emas. Persyaratan sangat mudah dan dapat diangsur tetap setiap bulan sesuai kemampuan konsumen. Produk Arrum BPKB dan arum emas ini memudahkan nasabah mendapatkan pinjaman uang dengan jaminan BPKB kendaraan atau emas.

\section{Amanah}

Produk amanah ini tersedia di seluruh outlet Pegadaian di seluruh Indonesia. Produk amanah ini diluncurkan bagi konsumen yang ingin membeli kendaraan bermotor baik mobil maupun sepeda motor. Konsumen dapat memilih sendiri kendaraan dan dealer yang diinginkan. Pegadaian Syariah memberikan dana talangan yang dapat dicicil tetap setiap bulan oleh konsumen sesuai kemampuan.

\section{Multi Pembayaran Online dan remitten}

Saat ini Pegadaian Syariah sudah mengembangkan bisnisnya. Untuk memenuhi keinginginan nasabah Pegadaian Syariah juga melayani pembayaran tagihan listrik, air, telepon, kartu hallo, BPJS, Asuransi Prudential, Suzuki Finance, top up Grab, pulsa hp, dan pulsa listrik. Semua ini bisa dilakukan lewat produk Multi Pembayaran Online (MPO). Untuk remitten Pegadaian Syariah menerima Westen Union untuk mengirim maupun menerima uang dan delima yaitu produk sejenis western union dapat digunakan untuk mengirim maupun menerima uang tanpa memiliki rekening bank. Fasilitas ini tersedia di outlet Pegadaian Syariah seluruh Indonesia.

\section{Jasa Titipan}

Demi rasa aman Pegadaian Syariah memiliki produk jasa titipan. Konsumen yang sering bepergian jauh dan dalam waktu agak lama, dapat menitipkan barang - barang dan 
surat - surat berharga di Pegadaian Syariah. Jasa titip yang dikenakan untuk barang barang dan surat - surat berharga Rp. 20.000/bulan/100 gr.

\section{Tabungan Emas}

Cara berinvestasi dapat dilakukan salah satunya di Pegadaian Syariah. Mulai dari murid - murid sekolah yang belum memiliki KTP hingga pelajar yang sudah memiliki KTP dapat berinvestasi sejak dini dengan resiko yang kecil melalui tabungan emas.

\section{Mulia dan Emasku}

Di Pegadaian Syariah ada juga investasi dengan sistem angsuran. Produk ini dikenal dengan produk mulia. Produk Mulia Pegadaian Syariah melayani investasi emas batangan dengan sisten angsuran tetap kepada konsumen. Produk ini bisa digunakan sebagai alternatif pilihan investasi untuk masa depan dan memiliki keunggulan yaitu investasi untuk membeli rumah, kendaraan, atau jaminan utuk pendaftaran ibadah haji selain itu ada produk emasku yang ditambah dengan jaminan asuransi jiwa. Produk mulia dan emasku ini berupa emas batangan bersertifikat. Ada 2 merek yang tersedia yaitu : ANTAM dan UBS.

\section{Definisi Sikap Konsumen}

Sikap menurut Maharani dan Darma (2018) adalah perilaku yang menunjukkan apa yang disukai dan tidak disukai konsumen sedangkan oleh Sunyoto, 2014 sikap merupakan interaksi manusia dengan objek tertentu. Definisi sikap konsumen menurut Kanten dan Darma (2017) yaitu faktor penting yang akan mempengaruhi keputusan konsumen, dimana hal ini sangat terkait dengan konsep kepercayaan dan perilaku. Dari definisi para peneliti, sikap memiliki makna bahwa sikap mempelajari kecenderungan pemberian tanggapan terhadap suatu objek, baik yang disenangi maupun tidak secara konsisten. Dapat ditarik kesimpulan bahwa sikap adalah suatu mental dan saraf sehubungan dengan kesiapan konsumen untuk menanggapi apa yang mereka sukai dan yang tidak disukai.

\section{Definisi Kepercayaan}

Menurut Swari dan Darma (2019) Kepercayaan adalah kekuatan yang seharusnya dijaga agar suatu produk tetap mendapat tempat di hati konsumen. Wibowo (2006); Hendhana dan Darma (2017) mendefinisikan kepercayaan atau trust merupakan nilai yang paling dihargai dalam hubungan dengan manusia dan kemungkinan sebagai konsep yang kurang dipahami ditempat kerja atau rasa percaya yang dimiliki orang satu dengan orang lainnya sedangkan Sopiah, 2008 mengutip dalam Morgan dan Hunt bahwa kepercayaan 
timbul karena adanya suatu rasa percaya terhadap organisasi yang memang memiliki kualitas yang dapat mengikat dirinya, seperti tindakan yang konsisten, kompeten, jujur, adil, bertanggungjawab, suka membantu, dan rendah hati. Kepercayaan tidak begitu saja dapat diakui oleh pihak lain, tetapi harus dimulai dari awal dan dapat dibuktikan. Kepercayaan merupakan salah satu komponen penting yang dapat mengembangkan suatu lingkungan kerja yang kondusif.

\section{METODE PENELITIAN}

Pada penelitian ini peneliti menggunakan metode kualitatif, dimana metode ini meneliti kehidupan social yang natural/alamiah. Desain penelitian yang digunakan yaitu desain penelitian kualitatif studi kasus, menurut Sugiyono, 2017 dimana jenis desain ini menggunakan pendekatan yang digunakan untuk menyelidiki dan memahami sebuah kejadian atau masalah yang telah terjadi dengan mengumpulkan berbagai informasi yang kemudian diolah untuk mendapatkan sebuah solusi agar masalah yang diungkapkan dapat diselesaikan. Penelitian ini mengambil tempat di PT Pegadaian Syariah Kartini Denpasar yang berlokasi di jalan Kartini no.69 Denpasar. Konsep yang digunakan dalam penelitian ini adalah manajemen Syariah, kepercayaan konsumen dan gadai emas.

Penelitian ini menggunakan pengumpulan data primer dan data sekunder. Data primer yang diperoleh yaitu langsung dari hasil wawancara oleh para informan yang dianggap berpotensi dalam memberikan informasi yang relevan dan sebenarnya di lapangan, seperti Pimpinan Cabang, Pengelola Agunan, kasir, nasabah muslim, dan nasabah non muslim yang setia bertransaksi di PT Pegadaian Syariah Kartini. Sedangkan data sekunder pada penelitian ini merupakan data yang diambil dari data transaksi PT Pegadaian Syariah Kartini Denpasar. Untuk menggunakan data primer dan sekunder digunakan beberapa teknik pengumpulan data yaitu wawancara dan studi dokumentasi, dengan penentuan informan dilakukan dengan teknik purposive sampling, dimana pemilihan informan adalah menurut kriteria tertentu dan disesuaikan dengan topik penelitian.

Analisis data pada penelitian ini merupakan kegiatan setelah data dari seluruh informan terkumpul. Teknik analisis data kualitatif terdiri dari reduksi data, penyajian data, dan penarikan kesimpulan. Hasil analisis tersebut diuji keabsahan dengan menggunakan verifikasi keabsahan hasil analisis teknik trianggulasi sumber, dimana menurut Sugiyono (2017), trianggulasi dalam pengujian kredibilitas ini diartikan sebagai pengecekan data dari berbagai sumber dengan berbagai cara, dan berbagai waktu. 


\section{PEMBAHASAN}

Dari hasil penelitian yang dilakukan melalui proses wawancara dengan beberapa informan di PT Pegadaian Syariah Kartini Denpasar, ditemukan bahwa Implementasi Syariah di PT Pegadaian Syariah Kartini telah diterapkan dan kepercayaan konsumen untuk gadai emas terus meningkat. Adanya transformasi dan peningkatan fasilitas untuk keperluan konsumen sangat bermanfaat. Konsumen yang semula hanya tau fitur produk PT Pegadaian Syariah hanya menerima gadai namun saat ini telah berkembang bertransformasi sesuai jaman.

\section{Manajemen Syariah}

Implementasi manajemen Syariah di PT Pegadaian Syariah Kartini sudah diterapkan. Dari hasil wawancara dan pengamatan peneliti, prosedur dan penjanjian transaksi sudah Syariah sesuai fatwa MUI. Realisasi manajemen Syariah di PT Pegadaian Kartini sesuai dengan pelindung gadai Syariah dalam pemenuhan prinsip - prinsip Syariah berpegang pada Fatwa DSN-MUI Nomor 25/DSN/MUI/III/2002 tentang rahn, Fatwa DSN-MUI Nomor 26/DSN-MUI/III/2002 tentang rahn emas, Fatwa DSN-MUI Nomor 68/DSN-MUI/III/2002 tentang rahn tasjily, Fatwa DSN-MUI 92/DSN-MUI/III/2002 tentang pembiayaan yang disertai dengan rahn (At Tamwil Al Mautsuq bi al Rahn) Amanah, Arrum, Rahn Tasjily tanah”. Setiap produk dan akad yang digunakan di PT Pegadaian Syariah Kartini dalam akad gadai sesuai hasil kajian Dewan Pengawas Syariah yang digariskan oleh fatwa - fatwa tentang gadai dan pembiayaan oleh Dewan Pengawas Syariah.

Penerapan manajemen Syariah di PT pegadaian Kartini sudah ada dalam perjanjian Syariah yaitu Akad Rahn dan Akad Mu'nah. Dimana dalam manajemen Syariah perjanjian harus transparan. Hal ini terlihat jelas pada akad Rahn dan Akad Mu'nah, dimana isi perjanjian tertulis jelas dan atas persetujuan antara Rahin dan murtahin. Begitu pula pada perjanjian produk mulia, perjanjian juga tertulis jelas dan disepakati antara kedua belah pihak. Untuk pembiayaan fidusia pun akad perjanjian transparan dan disetujuai antara Rahin dengan murtahin.

Apabila konsumen tidak dapat memenuhi kewajibannya untuk mengembalikan uang pinjaman sesuai perjanjian maka barang gadaian emasnya dapat digunakan untuk menutup semua kewajiban konsumen, dan apabila ada kelebihan hasil penjualan gadaian emas tersebut dan tidak diambil konsumen dalam waktu 1 tahun, maka dana tersebut akan dialokasikan oleh pihak murtahin kepada dinas sosial yang ditunjuk PT Pegadain Syariah Kartini sebagai Dinas yang mengelola dana tersebut. Sedangkan kewajiban konsumen yang tidak terpenuhi, 
apabila nilai gadaian emas rahin tidak cukup menutup kewajiban gadaian emasnya, murtahin tetap harus mengembalikan kepada PT Pegadaian Syariah Kartini.

\section{Kepercayaan Konsumen}

Masyarakat Indonesia pada umumnya telah mengenal emas sebagai salah satu investasi yang aman untuk masa depan. Harga emas yang setiap tahun meningkat, membuat masyarakat terbuka pemikirannya berinvestasi emas sebagai modal masa depan. Apabila masyarakat memerlukan dana cepat, tidak memerlukan prosedur yang ribet dan lama, dapat mempergunakan emas sebagai solusi yaitu gadai emas. Meskipun terlihat kecil, namun emas memiliki harga yang tinggi dan stabil. Prosedur dan persyaratan untuk gadai emas pun sederhana dan mudah. Masyarakat dapat tetap memiliki emas atau perhiasan mereka tanpa harus kehilangan emas atau nilai sejarah yang dimiliki dengan menggadaikan emasnya di PT Pegadaian Syariah Kartini. Selain aman, pinjaman yang diberikan oleh PT Pegadaian Syariah Kartini juga tinggi. Nilai pinjaman yang diberikan untuk gadai emas terhadap taksiran emas mencapai $95 \%$. Tempo yang diberikan mencapai 4 bulan, dengan tidak dikenakan bunga karena dalam manajemen Syariah Pegadaian tidak mengenal adanya riba. Konsumen dapat mencicil gadaian emasnya dengan mencicil uang pinjaman mereka beserta jasa titip dan administrasi yang telah disetujui antara Rahn dengan Murtahin.

Namun ada juga masyarakat yang belum mengetahui bahwa PT Pegadaian merupakan Badan Usaha Milik Negara (BUMN) yang merupakan lembaga keuangan non perbankan yang dimiliki negara, hal ini membuat konsumen berpikir sempit tentang PT Pegadaian Syariah kartini, ada juga konsumen yang merasa gengsi ke PT Pegadaian Syariah Kartini untuk gadaikan emas, sehingga menggunakan identitas orang lain untuk menggadaikan emasnya. Adanya status BUMN dan adanya produk Syariah membuat konsumen semakin yakin dan percaya bahwa emas yang mereka gadaikan di PT Pegadaian Syariah Kartini aman dan terjamin. Pelayanan PT Pegadaian Syariah Kartini mempengaruhi kepercayaan konsumen, selain Pimpinan Cabang yang komunikatif terhadap konsumen, pelayanan pegawai sampai pihak pengamanan juga sangat baik, sehingga konsumen nyaman untuk bertransaksi.

Selain gadai emas, saat ini PT Pegadaian Syariah telah memiliki produk dalam pembelian emas batangan secara cash atau angsuran baik ANTAM maupun UBS. PT Pegadaian Syariah memiliki produk emas Syariah ultimate, dimana angsuran emas batangan ini merupakan salah satu cara berinvestasi emas yang produknya dicover dengan asuransi jiwa apabila selama menggangsur terjadi sesuatu pada konsumen, hak waris yang diajukan 
mendapatkan santunan senilai 30 juta. Adanya berbagai produk di PT Pegadaian Syariah Kartini membuat konsumen lebih tertarik lagi untuk bertransaksi di PT Pegadaian Syariah Kartini. Berdasarkan hasil wawancara dengan konsumen, bertambahnya produk - produk selain gadai membuat konsumen senang karena tidak perlu ke tempat lain untuk melakukan pembayaran rutin bulanan seperti pembayaran listrik, telepon, air, asuransi, pengiriman maupun penerimaan uang melalui fitur remitten, pembiayaan kendaraan bermotor, top up grab, produk tabungan emas mulai saldo minimal 0.01 gr berkisar 7000 Rupiah. Untuk tabungan emas dapat dilakukan mulai usia dini, mendidik memperkenalkan budaya menabung emas sejak dini dan pembiayaan arum haji. PT Pegadaian memiliki sarana yang mengikuti jaman yaitu Pegadaian Digital Service (PDS). Layanan ini memiliki kemudahan untuk bertransaksi antara lain untuk gadai emas secara online, membayar jasa titip gadai, pengajuan pembiayaan fidusia, pembukaan rekening tabungan, pembelian pulsa HP, pembelian dan penjualan emas. PT Pegadaian juga memiliki produk arum haji, dimana produk ini diberikan oleh PT Pegadaian kepada konsumen yang berniat menunaikan ibadah haji. PT Pegadaian memberikan dana talangan kepada konsumen yang hendak mendaftar haji, dana talangan ini dapat diangsur sesuai kemampuan konsumen. PT Pegadaian bekerjasama dengan pihak perbankan Syariah untuk bersama - sama mendaftarkan konsumen ke Departemen Agama. Era transformasi ini, PT Pegadaian merubah paradigma masyarakat tentang PT Pegadaian, yang semula hanya dikenal tempat menggadaikan emas, namun saat ini PT Pegadaian telah memiliki berbagai macam produk. Dan tak kalah menariknya PT Pegadaian mempunyai fasilitas untuk milenial mager seperti The Gade Café. Disana nasabah dengan berbagai usia bisa menikmati minuman kopi, coklat, dan makanan kecil lainnya yang tersedia. Tersedia juga layanan Wifi gratis sehingga konsumen dapat menggunakan fasilitas tersebut.

\section{PENUTUP}

Berdasarkan dari hasil penelitian yang dilakukan di PT Pegadaian Syariah Kartini Denpasar dan hasil pembahasan diatas, maka dapat disimpulkan bahwa Implementasi Syariah di PT Pegadaian Syariah Kartini telah diterapkan dan kepercayaan konsumen untuk gadai emas terus meningkat. Adanya pelayanan yang exellent, peningkatan fasilitas dan beragam produk yang diperlukan konsumen sangat bermanfaat. Konsumen yang semula hanya tau fitur produk PT Pegadaian Syariah hanya menerima gadai namun saat ini telah berkembang bertransformasi sesuai jaman. 
Implementasi manajemen Syariah di PT Pegadaian Syariah Kartini sudah diterapkan.

Dari hasil wawancara dan pengamatan peneliti prosedur dan perjanjian transaksi sudah menggunakan manajemen Syariah sesuai fatwa MUI. Realisasi manajemen Syariah di PT Pegadaian Kartini sesuai dengan pelindung gadai Syariah dalam pemenuhan prinsip - prinsip Syariah berpegang pada fatwa DSN - MUI No.25/DSN-MUI/III/2002 tentang Rahn dan DSN - MUI No.26/DSN-MUI/III/2002 tentang Rahn emas, Fatwa DSN-MUI Nomor 68/DSNMUI/III/2002 tentang rahn tasjily, Fatwa DSN-MUI 92/DSN-MUI/III/2002 tentang pembiayaan yang disertai dengan rahn (At Tamwil Al Mautsuq bi al Rahn) Amanah, Arrum, Rahn Tasjily tanah". Adanya status BUMN dan adanya produk Syariah membuat konsumen semakin yakin dan percaya bahwa emas yang mereka gadaikan di PT Pegadaian Syariah Kartini aman dan terjamin. Pelayanan PT Pegadaian Syariah Kartini mempengaruhi kepercayaan konsumen, selain Pimpinan Cabang yang komunikatif terhadap konsumen, pelayanan pegawai sampai pihak pengamanan juga sangat baik, sehingga konsumen nyaman untuk bertransaksi. Era transformasi ini, PT Pegadaian merubah paradigma masyarakat tentang PT Pegadaian, yang semula hanya dikenal tempat menggadaikan emas, namun saat ini PT Pegadaian telah memiliki berbagai macam produk.

Implikasi hasil penelitian ini bagi PT Pegadaian Syariah Kartini adalah mengetahui karakteristik konsumen untuk menentukan sikap dalam pengambilan produk Syariah sesuai dengan kebutuhan dan keinginan sehingga konsumen merasa tertarik, nyaman, dan percaya bertransaksi di PT Pegadaian Syariah Kartini.

Dari hasil pembahasan pada bab sebelumnya dimana adanya keterbatasan pada penelitian ini, oleh sebab itu untuk peneliti selanjutnya diharapkan lebih banyak membahas mengenai terobosan terkini demi memperoleh kepercayaan konsumen lebih maksimal. Dengan kemajuan jaman dan teknologi tentunya diperlukan masukan yang lebih banyak dan bermanfaat demi meningkatkan penjualan dan kesejahteraan karyawan sehingga bisa memberikan pelayanan terbaik demi menunjang kepercayaan konsumen. 


\section{DAFTAR PUSTAKA}

Abubakar dan Astuti. (2012). Pranata Gadai Sebagai Alternatif Pembiayaan Berbasis Kekuatan Sendiri (Gagasan Pembentukan UU Gadai). Penelitian Fakultas Hukum Universitas Padjajaran Bandung, dalam mimbar Hukum.

Adil, U. (2017). Bisnis Syariah di Indonesia Hukum dan Aplikasinya. Edisi Pertama. Jakarta: Mitra wacana Media.

Hamali, A.Y. (2016). Cetakan Pertama. Pemahaman Manajemen Sumber Daya Manusia. Jakarta: CAPS (Center for Academic Publishing Service).

Hadiana. (2015). Analisis Peraturan dan Mekanisme Produk Kredit pada Pegadaian Konvensional dan Syariah Tahun 2015. Jurusan Pendidikan dan Ekonomi. Universitas Pendidikan Ganesha. Singaraja, Indonesia.

Hendhana, S., and Darma, G.S. (2017). Service Quality Rumah Sakit dan Efeknya terhadap Patient Satisfaction, Perceived Value, Trust, dan Behavioral Intention, Jurnal Manajemen \& Bisnis, 14 (1): 37-55.

Kanten, I.K., and Darma, G.S. (2017). Consumer Behaviour, Marketing Strategy, Customer Satisfaction, and Business Performance, Jurnal Manajemen \& Bisnis, 14 (2): 143-165. Laili, N. (2019). Pelaksanaan Sistem Akuntansi Pemberian Kredit dan Pelunasannya pada Kanda XI Perum Pegadaian Jember. Universitas Jember.

Maharani, I.G.A.P.D., and Darma, G.S. (2018). Consumer Purchasing Behavior Analysis on Impulse Buying, Jurnal Manajemen \& Bisnis, 15 (3): 16-37.

Moorhead, G., Ricky W.G. (2013). Perilaku Organisasi : Manajemen Sumber Daya Manusia dan Organisasi. Jakarta: Salemba Empat.

Nasution, R.S. (2016). System Operasional Pegadaian Syariah Berdasarkan Surah AlBaqarah 283 pada PT Pegadaian (Persero) Cabang Syariah Gunung Sari Balikpapan, Jurnal Ekonomi dan Bisnis Islam, 1 (2): 93-119.

Sudaryono. (2017). Pengantar Manajemen : Teori dan Kasus. Cetakan Pertama. Yogyakarta: CAPS (Center for Academic Publishing Service).

Sugiyono. (2017). Metode Penelitian Kuantitatif, kualitatif, dan R \& D. CV. Alfabeta.

Syafuri, H. B. (2014). Aktivitas Gadai Syariah dan Implikasinya Terhadap Produktivitas Masyarakat di Provinsi Banten, Al-'Adalah, XII (2).

Sunyoto, D. (2014). Cetakan kedua. Konsep Dasar Riset Pemasaran dan Perilaku Konsumen. Yogyakarta: CAPS (Center for Academic Publishing Service).

Suhariyono, E.S. (2015). Pegadaian Syariah dan Akad Teknik Tasikmalaya. https://uangteman.com 
Sumarwan, U. (2014). Perilaku Konsumen Teori dan Penerapannya dalam Pemasaran. Bogor: Ghalia Indonesia.

Swari, D.A.K.B.A., and Darma, G.S. (2019). Kepercayaan Lintas Generasi Dalam Penggunaan Social Media dan Electronic Word of Mouth, Jurnal Manajemen Bisnis, 16 (4): $145-161$.

Wibowo. (2006). Manajemen Perubahan. Jakarta: PT Raja Grafindo Persada. 